\title{
Participatory Assessment of Resources and Needs of Upland Communities: A Case in Inopacan, Leyte, Philippines
}

\author{
Milagros C. Bales ${ }^{1}$, Editha G. Cagasan², Ma. Aurora Teresita W.
} Tabada $^{3}$, Ma. Victoria Stephane G. Asio ${ }^{2}$, Junette Dawn Baculfo ${ }^{3}$, Loren Gemali Flandez ${ }^{4}$, Arsenio D. Ramos ${ }^{5}$ and Warren D. Come ${ }^{6}$

\author{
${ }^{1}$ Department of Community Development and Extension; ${ }^{2}$ Department of \\ Development Communication; ${ }^{3}$ Institue of Strategic Research and Development \\ Studies; ${ }^{4}$ Department of Economics; ${ }^{5}$ Department of Horticulture; ${ }^{6}$ Deparment of \\ Animal Science, Visayas State University, Visca, Baybay City, Leyte, 6521-A \\ Philippines
}

\begin{abstract}
Experiences of past projects show that interventions would more likely succeed if these are designed considering the needs and resources of the target beneficiaries. To achieve this end, participatory rural appraisals (PRAs) were conducted in three barangays of Inopacan, Leyte with marginal upland areas. The PRAs were participated by 64 community residents representing almost all sectors. Tools used in data gathering were seasonal calendar, historical timeline, Venn diagram, household labor allocation, household decision-making, livelihood analysis, and problem tree analysis. Results showed that residents' main livelihood are farming and livestock raising. Major crops planted are coconut, corn, rootcrops, and banana; while animals raised include goats, swine, native chickens and carabaos. Due to limited water supply in the barangays, farmers have to depend on rainfed farming system. To augment family income, some women engage in backyard gardening, and in food processing and selling. Results also revealed that they have experienced problems like infertile soils, and Brontispa longissima infestation which reduced productivity of coconut. The FGD participants expressed that many people in their locality need other livelihood options to supplement their unstable income from coconut. The livelihood activities that can be enhanced through trainings and technical assistance include farming, animal raising and food processing. Results have implication in planning for more sustainable resource-based management.
\end{abstract}

Keywords: Participatory rural appraisal, upland barangays, community needs, livelihood options

Correspondence: M.C. Bales Address: Department of Community Development and Extension, Visayas State University, Visca Baybay City, Leyte, 6521-A, Philippines Email: mila bales@yahoo.com DOI: 10.32945/atr36s18.2014 
Participatory Assessment of Resources and Needs of Upland Communities

\section{INTRODUCTION}

The Philippine uplands are considered risk-prone and vulnerable areas due to inappropriate land use by the expanding number of upland dwellers (Mercado and Sanchez). However, even with these conditions, majority of upland households obtain their main sources of livelihoods from land-based activities. Thus, there is significant number of upland communities in the Philippines that are living below the poverty threshold. According to Sajise and Ganapin, (1990), the bio-physical and ecological instability of uplands caused increasing poverty and social costs among upland communities. Hence, in upland development, the issue of resource base sustainability, have to be addressed.

Experiences of past projects show that the participation of the target implementers and beneficiaries is a vital ingredient in the planning of activities for upland developments. Participation helps clarify and stabilize communications and power relationships between stakeholders(Kapoor, 2001). It encourages ownership, commitment and accountability among community residents. As stated by Sajise and Ganapin (1990), one way to promote community participation in development schemes is through the use of assessment methods such as Rapid Rural Appraisal (RRA) or Participatory Rural Appraisal (PRA). PRA is a method used to assess community needs and resources. It presents a growing array of approaches and methods that enable local people to share, enhance, and analyze their knowledge of life and conditions, as well as to plan and act (Chambers, 1994.

In development work, PRA has become a commonly accepted methodology of collecting benchmark data as basis for planning interventions in the areas of natural resource management, health, crop production improvement, education, and others (Mosse, 1994). PRA approaches and methods have given opportunities to officials, scientists and academics to come face-to-face with locals in an informal and nonintimidating mode which provide both sides with exciting, relevant and enjoyable learning experiences (Chambers, 1994). PRA techniques also draw on informants' previously unrecognized abilities of diagrammatic and symbolic representation through range of mapping and other techniques usable by illiterate people(Mosse, 1994).

Realizing the importance of analyzing the needs and resources of communities as basis for planning and designing possible interventions to achieve greater impact, and considering the essential concepts and 
principles PRA methodologies embrace, this study sought to determine and analyze the needs and resources of the three identified sites in Inopacan as bases for designing initiatives for enhancing productivity and environmental quality of the uplands. The qualitative PRA data collected will complement with the in-depth profiling on the socio-economic, agrolivestock-ecosystems and political conditions of the residents in the three sites conducted in another study under the project.

\section{METHODOLOGY}

\section{Selection of Research Sites}

The study was conducted in the three barangays (villages) of Inopacan, Leyte, namely: Linao, Guinsangaan and Marao (Fig.1). These sites were selected as suggested by the Local Government Unit (LGU) of Inopacan during the team's first walk-through visit, and also because these areas were the current pilot sites of the different PHERNet projects (i.e. crop production, post-harvest, livestock raising and others). Accessibility to the sites was also considered in the selection process.

Why PRA?

One of the ways to assess needs and resources of communities is through the use of Participatory Rural Appraisal (PRA). In PRA, outsiders (i.e. researchers, academics, etc.) encourage and allow the local people to dominate in discussions, analyze information and to plan (Chambers, 1994). This enables the local people to own and retain more information, identify their priorities for action, and then determine and control that action.

PRA tools and processes are able to reveal local people's capacity to analyze and present their knowledge graphically, i.e. through maps, models, estimates and ranks, and diagrams. Diagramming and visual sharing can yield information that is visible and verified, and amended and owned by the participants. Also, the sequences of tools are powerful in increasing the commitment of participants to further actions (DENR-UDP, 1994). 


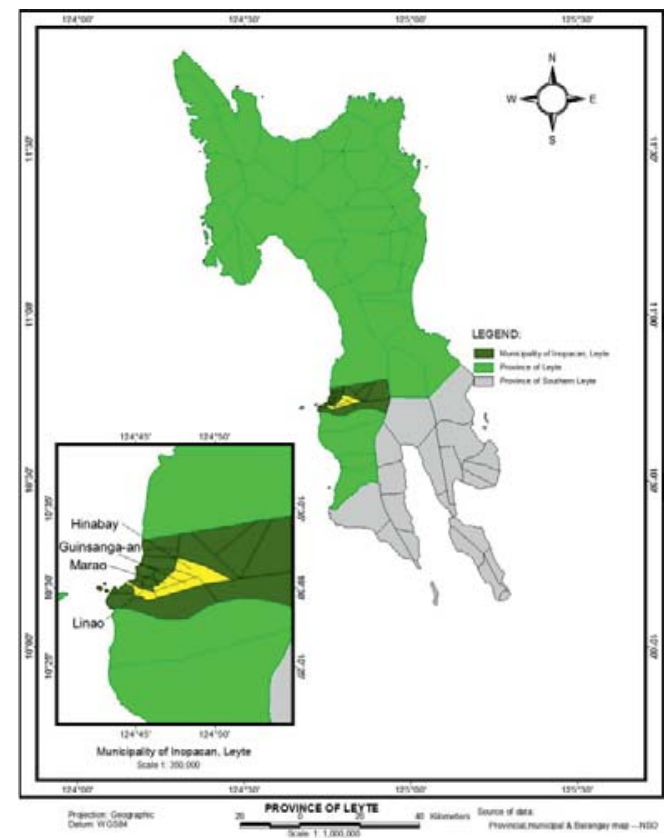

Figure 1. Map of Inopacan, Leyte, Philippines

Moreover, according to Chambers (1994), since PRA encourages group participation, sensitive topics can be discussed freely compared to the traditional questionnaire interviews, which cannot elicit such information when individuals would not wish to discuss them alone with an outsider.

\section{Selection of PRA Facilitators and Participants}

The PHERNet researchers composed of experts from the social science, crops and livestock disciplines, who have knowledge in the conduct of PRA, served as facilitators of the different focus group discussions.

To select the PRA participants, the team pre-arranged with the officials. In each barangay, the team requested representatives from upland farmers, women, young people, elderly, and local leaders. This was intended to get varied information from these different groups of stakeholders. Also, this makes it more inclusive if the planning process allows the maximum participation of the different groups of people in the community (DENR-UDP, 1994). 


\section{Data Gathering}

As a protocol, the project team made initial arrangements with the barangay officials particularly with the barangay chairman (village leader) and Councilor for Agriculture of the three barangays: Linao, Guinsangaan, and Marao in Inopacan, Leyte.

A number of PRA tools (Table 1) were selected to collect data from the sites as . These were walk through, historical timeline, seasonal calendar, Venn diagram, household labor allocation, livelihood analysis, decision making process, and problem analysis. Secondary data were also secured from the barangay offices and from the Municipal Planning Development Office (MPDO) to back up data collected after the walk through.

Separate PRA sessions, each lasting for a day, were conducted for each barangay (Figure 2). For Barangays Guinsangaan and Marao, the participants were divided into two groups since more than 20 residents from each barangay attended the activity. The first group tackled on social and resource mapping, historical timelines, Venn diagramming and wealth ranking. The other group covered the household labor allocation, livelihood analysis, household decision making process, and problem tree analysis. On the other hand, participants in Sitio Batuan, Linao were no longer divided into two groups since only 15 attended due to conflict of other activities.

To hold all participants for the day, the team distributed snacks and lunch. A total of 64 participants took part in the PRA; 15 from Linao, 22 from Guinsangaan, and 27 from Mara-o. The participants were a mix of farmers, housewives, community leaders, young people and senior citizens.

\section{Data Analysis}

Data collected in the field were encoded and subjected to thematic and trend analysis. These were presented using tables, graphs, charts and narrative descriptions. 
Participatory Assessment of Resources and Needs of Upland Communities

Table 1. Tools used during the PRA in the three study sites and the corresponding activities and data collected.

\begin{tabular}{|c|c|}
\hline PRA Tools Used & Data Collected \\
\hline $\begin{array}{l}\text { Walk through } \\
\text { (transect walk) }\end{array}$ & $\begin{array}{l}\text { - Ocular observations of the sites cutting } \\
\text { across agro-ecological zones. }\end{array}$ \\
\hline $\begin{array}{l}\text { 2. Social and resource } \\
\text { maps }\end{array}$ & $\begin{array}{l}\text { - Mapping of the location of houses of all } \\
\text { residents, schools, churches, village centers, } \\
\text { and other important infrastructures } \\
\text { including crops and livestock and other } \\
\text { natural resources }\end{array}$ \\
\hline 3. Historical Timeline & $\begin{array}{l}\text { - Significant events that happened in the } \\
\text { community which has influence on the } \\
\text { physical, farming, cultural, and other } \\
\text { changes occurring in the area. }\end{array}$ \\
\hline 4. Seasonal Calendar & $\begin{array}{l}\text { - Cropping pattern } \\
\text { - Rainfall pattern } \\
\text { - On-farm/off-farm activities integrating who } \\
\text { does what }\end{array}$ \\
\hline 5. Venn Diagram & $\begin{array}{l}\text { - Existing organizations/institutions working } \\
\text { in the community (educational, } \\
\text { credit/financing, religious, social, political, } \\
\text { etc.) } \\
\text { - Integrate reasons/constraints in the } \\
\text { participation }\end{array}$ \\
\hline $\begin{array}{l}\text { 6. Household Labor } \\
\text { Allocation }\end{array}$ & $\begin{array}{l}\text { - Mapping round-the-clock activities in the } \\
\text { household indicating who does what } \\
\text { (Husband, wife, children, extended, if there } \\
\text { are) }\end{array}$ \\
\hline 7. Livelihood Analysis & $\begin{array}{l}\text { - Identifying possible livelihoods based on } \\
\text { existing resources, interests and capabilities }\end{array}$ \\
\hline $\begin{array}{l}\text { 8. Household Decision } \\
\text { making process }\end{array}$ & $\begin{array}{l}\text { - Control and access of resources; who } \\
\text { decides on major activities at the household } \\
\text { and farm level. }\end{array}$ \\
\hline $\begin{array}{l}\text { 9. Problem tree } \\
\text { analysis }\end{array}$ & - Traces the causes of the core problem \\
\hline
\end{tabular}




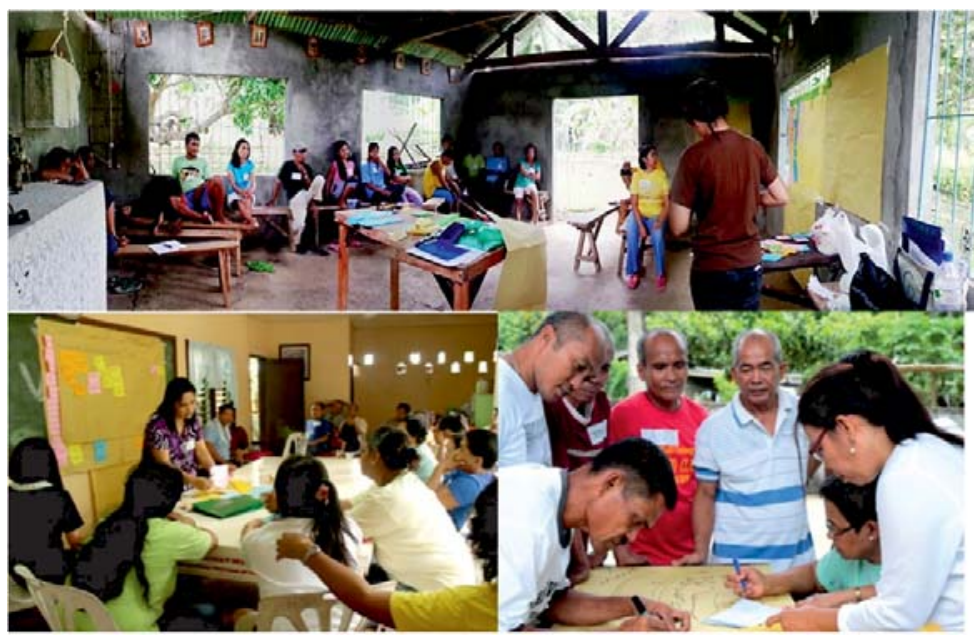

Figure 1. Participatory Rural Appraisals (PRAs) in study sites in Inopacan, Leyte.

\section{RESULTS AND DISCUSSION}

\section{Historical Description of the Study Sites}

The barangays of Linao, Giunsangaan and Marao are contiguously located in the Eastern part of the Municipality of Inopacan. Guinsangaan used to be one of the sitios of Marao but in 1972 it was converted into a barangay. The name Guinsangaan was coined after the two rivers that branched out from barangay Can-angay and barangay Marao. On the other hand, the name "Linao" was also derived when placid and calm small lakes were formed after the strong hurricane struck the place in 1925.

Since the 1940s, the mountain areas that bounded along the southern side of Sitio Batuan, going up Guinsangaan and Marao, were already cogonal. However, only big trees like Acacia and countable dipterocarps could be found, since according to old folks, trees were cut for firewood. In the early years, only a few were residing in those barangays because of the difficult road system. Historical timeline data (Table 2) revealed that the people experienced strong typhoons like Amie (1950), Asyang (1972) and Besing (1982), which caused severe devastation due to strong floods. This was followed by a long drought in 1983 that lasted for nine months. These calamities tremendously destroyed the residents' crops and livestock affecting their livelihoods at that time.

Another significant event that took place particularly in Linao was that 
Participatory Assessment of Resources and Needs of Upland Communities

farmers used to grow traditional upland rice or lubang since 1960s but was discontinued due to lack of water supply and because new varieties were introduced. Interestingly, in World War II, a brave woman named Julia Manapsal, a resident of Marao, led the Guerrilla warfare. After the liberation from the Americans, new settlers came over and roads were constructed.

Table 2. Historical description of the three sites.

\begin{tabular}{|c|c|c|c|}
\hline \multirow[b]{2}{*}{ Year } & \multicolumn{3}{|c|}{ Significant events } \\
\hline & Linao & Guinsangaan & Mara-o \\
\hline $\begin{array}{l}\text { Early } \\
\text { years }\end{array}$ & Forested & Forested & Forested \\
\hline 1940 & Cogonal & Cogonal & $\begin{array}{l}\text { No road yet, just trail; } \\
\text { cogonal already, with } \\
\text { some big trees like } \\
\text { Acasia, few people } \\
\text { residing }\end{array}$ \\
\hline 1951 & $\begin{array}{l}\text { Typhoon Amy, } \\
\text { crops } \\
\text { destroyed, } \\
\text { trees fall down }\end{array}$ & $\begin{array}{l}\text { Typhoon Amy, } \\
\text { crops destroyed, } \\
\text { trees fall down }\end{array}$ & $\begin{array}{l}\text { Strong typhoon Amy, } \\
\text { crops destroyed, } \\
\text { trees fall down }\end{array}$ \\
\hline 1972 & $\begin{array}{l}\text { Tyhoon Asyang, } \\
\text { heavy flooding }\end{array}$ & $\begin{array}{l}\text { Converted to } \\
\text { Barangay } \\
\text { Asyang, heavy } \\
\text { flooding }\end{array}$ & $\begin{array}{l}\text { Asyang, heavy } \\
\text { flooding }\end{array}$ \\
\hline 1983 & Long drought & $\begin{array}{l}\text { Long drought, } \\
\text { Electricity LEYECO } \\
\text { installed }\end{array}$ & Long drought \\
\hline 1990 & $\begin{array}{l}\text { Strong typhoon } \\
\text { "Ruping" }\end{array}$ & $\begin{array}{l}\text { Strong typhoon } \\
\text { "Ruping" }\end{array}$ & $\begin{array}{l}\text { Strong typhoon } \\
\text { "Ruping" }\end{array}$ \\
\hline $\begin{array}{l}1990- \\
1993\end{array}$ & $\begin{array}{l}\text { Repair of water } \\
\text { tank reservoir }\end{array}$ & $\begin{array}{l}\text { Water reservoir } \\
\text { constructed }\end{array}$ & $\begin{array}{l}\text { Water reservoir } \\
\text { constructed }\end{array}$ \\
\hline
\end{tabular}


Bales et al.

\section{Resources available}

In 2006, Inopacan had a total population of 19,276 (Municipal Profile of Inopacan, 2007). Of the total population, about $12 \%$ comprise the three barangays with Marao being the most populous $(1,073)$, followed by Linao (819), and Guinsangaan (394).

As shown in the social and resource maps (Figures 3, 4 \& 5) and the seasonal calendars (Figures 6 \& 7), the main crops grown are coconut, corn, banana, and rootcrops (i.e. sweet potato and cassava). Minor crops are vegetables, and some fruit trees (jackfruits, mango, rambutan, and durian). Some ornamentals are also decorated in front yards of majority of the houses in all sites. Aside from crops, residents also raise livestock including swine, native chickens, ducks, goats, cattle and turkey.

Although there are sources of water for drinking and irrigation (found in Marao), these could not suffice the needs of the communities especially during drought. Because of this, farmers have to depend on rainfed farming system.

Infrastructures present in the barangays include covered courts, chapels, barangay hall and farm to market roads. The barangays also have health centers but medical needs could not be efficiently and effectively addressed because midwives and doctors rarely visit the areas. Moreover, schools and chapels are present in all sites. In fact, Marao has complete high school levels where youth in the nearby barangays study.

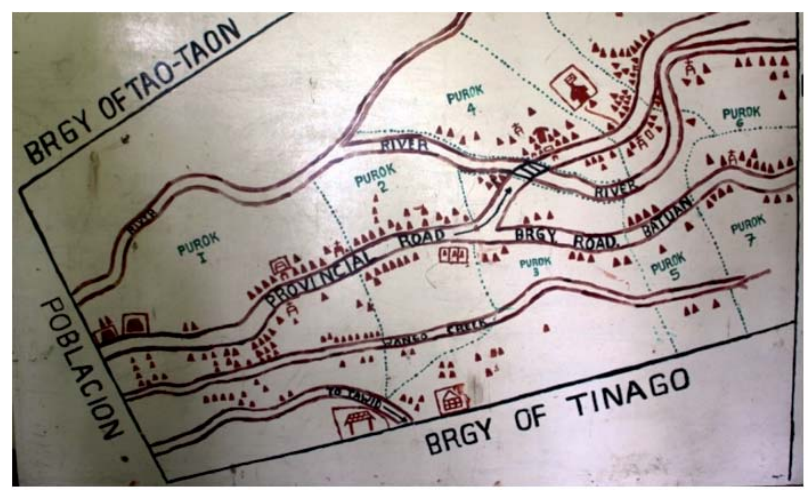

Figure 3. Social and resource map of Barangay Linao, Inopacan, Leyte 


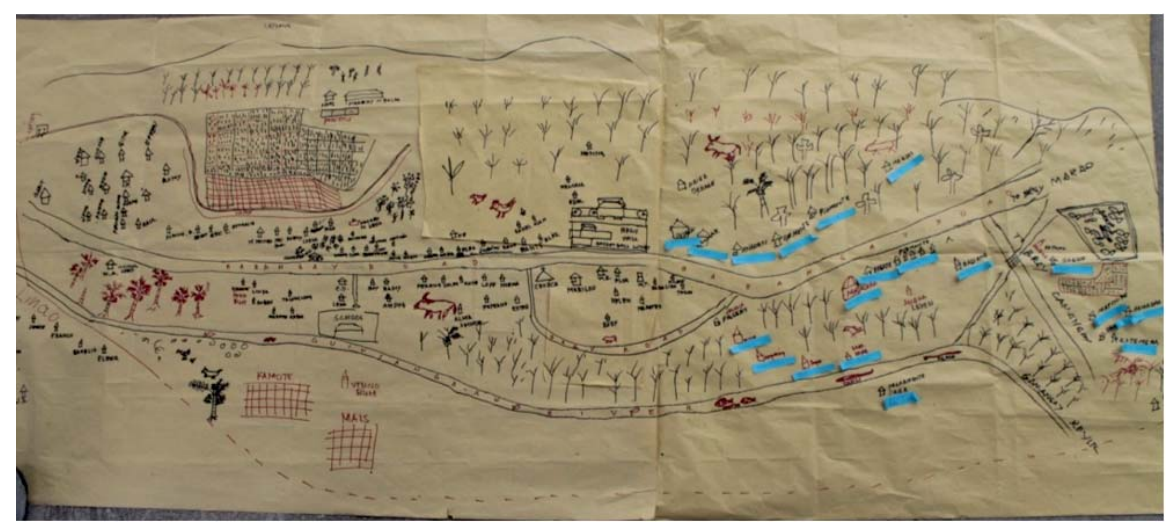

Figure 4. Social and resource map of Barangay Guinsangaan, Inopacan, Leyte.

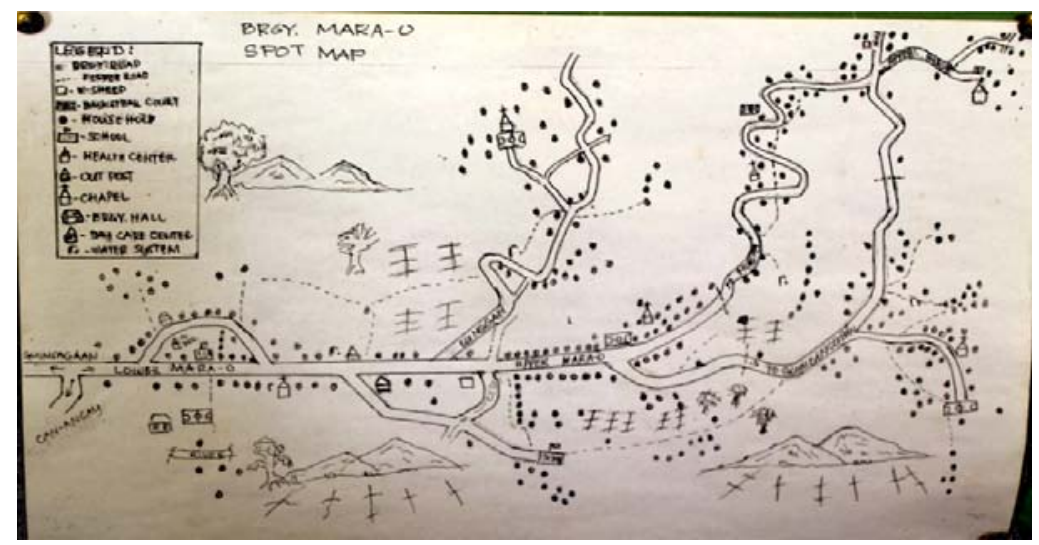

Figure 5. Social and resource map of Barangay Marao, Inopacan, Leyte.

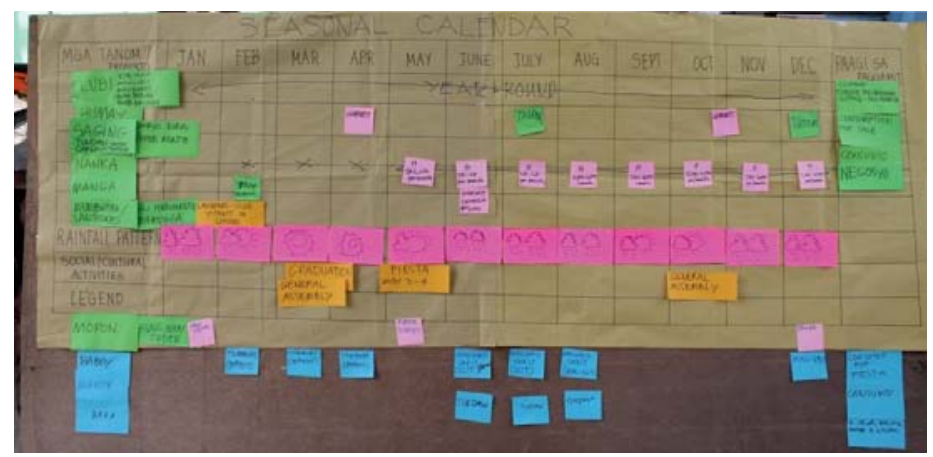

Figure 6. Seasonal calendar of Barangay Guinsangaan, Inopacan, Leyte. 


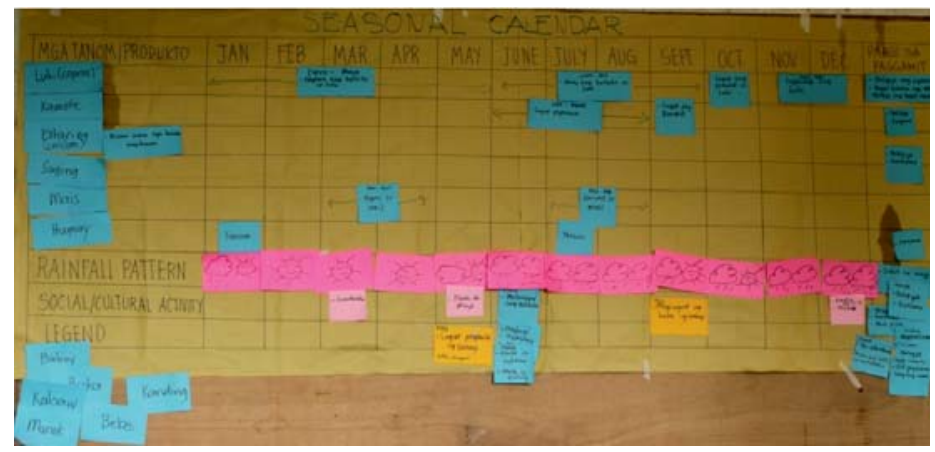

Figure 7. Seasonal calendar of Barangay Marao, Inopacan, Leyte.

\section{Livelihood activities}

Data revealed that the people mainly depend on farming (coconut farming) and livestock raising, as livelihood sources. In addition, some women are engaged in backyard gardening, and food processing and selling, while the men are able to earn income from bamboo furniture making. Other residents survived with labor wage, habal-habal driving, tuba gathering, and charcoal making and selling.

\section{Household dynamics}

As to labor allocation within families (Table 3), wives are generally responsible in household chores such as preparing food, cleaning the house, washing clothes and dishes, and preparing children for school. Likewise, husbands do farm activities like planting, weeding, harvesting and drying coconut, and tuba gathering.

Activities wherein all family members can work together include farm weeding, grazing carabaos, raising animals, handicraft making (bags), and cleaning bamboo slabs. The sons usually help the fathers in farm activities while the daughters help mothers in household chores when not in school.

According to the residents, the family decision making process (Table 4) is associated with the household roles and responsibilities family members assumed. For instance, decisions regarding farm operations are done by husbands while decisions related to household chores and budgeting are performed by women. Interestingly, both husbands and wives decide regarding schooling of their children. 
Participatory Assessment of Resources and Needs of Upland Communities

Results of the household decision making exercise showed that the decision making process is based on several factors, including: who earns the income, amount of money involved, knowledge of the activity or work and presence of husband or wife. If the husband is out, the wife decides for the family and vice versa. It was also reported that parents consulted their children on major decisions for the family. These data revealed that patriarchal pattern of influence is fading out.

Table 3. Household labor allocation in the three barangays in Inopacan, Leyte.

\begin{tabular}{|c|c|c|c|c|}
\hline \multirow[b]{2}{*}{ Activity } & \multicolumn{4}{|c|}{ Who does the work? } \\
\hline & Men & Women & $\begin{array}{l}\text { Male } \\
\text { Children }\end{array}$ & $\begin{array}{l}\text { Female } \\
\text { Children }\end{array}$ \\
\hline $2: 00 \mathrm{am}$ & $\begin{array}{l}\text { Listening } \\
\text { to Radio }\end{array}$ & & & \\
\hline 4:00 am & & $\begin{array}{l}\text { Prepare for } \\
\text { breakfast }\end{array}$ & & \\
\hline $\begin{array}{l}\text { 6:00-7:00 } \\
\text { am }\end{array}$ & Breakfast & Breakfast & & \\
\hline $\begin{array}{l}\text { 7:00- } \\
\text { 9:00am }\end{array}$ & Work & $\begin{array}{l}\text { Household } \\
\text { Chores }\end{array}$ & School & \\
\hline $10: 00 \mathrm{am}$ & & $\begin{array}{l}\text { Preparation for } \\
\text { lunch }\end{array}$ & & \\
\hline $12: 00 \mathrm{nn}$ & Lunch & Lunch & Lunch & Lunch \\
\hline $1: 30 \mathrm{pm}$ & Work & $\begin{array}{l}\text { Household } \\
\text { chores }\end{array}$ & $\begin{array}{l}\text { Household } \\
\text { chores }\end{array}$ & $\begin{array}{l}\text { Household } \\
\text { chores }\end{array}$ \\
\hline $4: 30 \mathrm{pm}$ & & $\begin{array}{l}\text { Fetch Children in } \\
\text { school }\end{array}$ & & \\
\hline $5: 00 \mathrm{pm}$ & & $\begin{array}{l}\text { Preparation for } \\
\text { supper }\end{array}$ & & \\
\hline $\begin{array}{l}\text { 6:00-7:00 } \\
\text { pm }\end{array}$ & Supper & Supper & Supper & Supper \\
\hline 7:00 pm & & $\begin{array}{l}\text { Household } \\
\text { chores }\end{array}$ & $\begin{array}{l}\text { Household } \\
\text { chores }\end{array}$ & $\begin{array}{l}\text { Household } \\
\text { chores }\end{array}$ \\
\hline 8:00 pm & Rest & $\begin{array}{l}\text { Watch } \\
\text { TV/Household } \\
\text { chores }\end{array}$ & $\begin{array}{l}\text { Watch TV/ } \\
\text { Do } \\
\text { assignment }\end{array}$ & $\begin{array}{l}\text { Watch TV/ } \\
\text { Do } \\
\text { assignment }\end{array}$ \\
\hline
\end{tabular}


Table 4. Household decision making process in the three barangays in Inopacan, Leyte.

\begin{tabular}{|c|c|c|c|c|c|c|}
\hline Activities & \multicolumn{2}{|c|}{ Linao } & \multicolumn{2}{|c|}{ Guinsangaan } & \multicolumn{2}{|c|}{ Marao } \\
\hline $\begin{array}{l}\text { House } \\
\text { Construction }\end{array}$ & & & $\mathrm{x}$ & $\mathrm{x}$ & $\mathrm{x}$ & \\
\hline Borrow Money & $x$ & $\mathrm{x}$ & $x$ & $\mathrm{x}$ & & \\
\hline $\begin{array}{l}\text { Purchase of } \\
\text { appliances }\end{array}$ & $\mathrm{x}$ & $\mathrm{x}$ & $\mathrm{x}$ & $\mathrm{x}$ & $\mathrm{x}$ & \\
\hline Livelihood & $\mathrm{x}$ & $\mathrm{x}$ & $\mathrm{x}$ & $\mathrm{x}$ & & \\
\hline Farm Chores & $\mathrm{x}$ & & $\mathrm{x}$ & & $\mathrm{X}$ & \\
\hline $\begin{array}{l}\text { Household } \\
\text { Chores }\end{array}$ & & $\mathrm{x}$ & & $\mathrm{x}$ & & $\mathrm{x}$ \\
\hline $\begin{array}{l}\text { Marketing of } \\
\text { Products }\end{array}$ & & & $\mathrm{x}$ & $\mathrm{x}$ & $\mathrm{x}$ & \\
\hline $\begin{array}{l}\text { Attendance to } \\
\text { meetings and } \\
\text { seminars }\end{array}$ & & & & $\mathrm{x}$ & & \\
\hline $\begin{array}{l}\text { Children's } \\
\text { schooling }\end{array}$ & $\mathrm{x}$ & $\mathrm{x}$ & $\mathrm{x}$ & $\mathrm{x}$ & $\mathrm{x}$ & $\mathrm{x}$ \\
\hline $\begin{array}{l}\text { Participation in } \\
\text { church \& } \\
\text { community } \\
\text { organizations }\end{array}$ & & & & & & $\mathrm{X}$ \\
\hline $\begin{array}{l}\text { Discipline of } \\
\text { Children }\end{array}$ & $\mathrm{x}$ & $\mathrm{x}$ & & & & \\
\hline Budgeting & & $\mathrm{X}$ & & & & \\
\hline Animal Raising & $\mathrm{x}$ & $\mathrm{x}$ & & & & \\
\hline
\end{tabular}

\section{Problems and Needs}

There are a number of problems, needs and issues confronting marginal upland farmers as they face the challenges of climate change and soil vulnerability. When the team conducted the livelihood analysis, by examining their existing and possible/proposed livelihoods, there were a number of problems listed (Table 5). 
Participatory Assessment of Resources and Needs of Upland Communities

Table 5. Problems and needs of the three barangays in Inopacan, Leyte

\begin{tabular}{ll}
\hline Problems and needs & Description \\
\hline Unfavorable conditions & $\begin{array}{l}\text { Lack of water and irrigation systems in the } \\
\text { for crop production }\end{array}$ \\
& $\begin{array}{l}\text { community is the reason why residents are } \\
\text { Moreover, declining soil fertility leads to low } \\
\text { production of crops planted. }\end{array}$
\end{tabular}

Occurrence of pests and Informants revealed that their crops (i.e. diseases coconut, abaca, banana) trees are infested with different pests and diseases (Brontispa longissima for coconut, ABTV and alhoheris for abaca, bugtok for banana). Thus, affecting the yield of their crops.

\begin{tabular}{ll}
\hline $\begin{array}{l}\text { Young generations are no } \\
\text { longer interested in } \\
\text { farming }\end{array}$ & $\begin{array}{l}\text { According to informants, their children have } \\
\text { lost interest in farming, which have resulted } \\
\text { in low production of crops. }\end{array}$ \\
\hline $\begin{array}{l}\text { No space for planting food } \\
\text { crops }\end{array}$ & $\begin{array}{l}\text { Participants said that they have no more } \\
\text { space to plant food crops like vegetables and } \\
\text { rootcrops because the relatively more fertile } \\
\text { part of the barangays are planted with } \\
\text { coconut; the upper portions are infertile and } \\
\text { not suitable for crop production. }\end{array}$ \\
\hline Low price of copra & $\begin{array}{l}\text { The price of copra has decreased but the } \\
\text { wage for laborers that they hire to make } \\
\text { copra, remained very high. This is why they } \\
\text { could not earn enough income from their } \\
\text { copra, thus limiting their ability to buy their } \\
\text { basic needs and send their children to } \\
\text { school. }\end{array}$ \\
\hline $\begin{array}{l}\text { In raising livestock and poultry, residents } \\
\text { have also experienced problems with } \\
\text { diseases that infect their animals. }\end{array}$ \\
animals
\end{tabular}




\section{Unfavorable conditions for crop production}

For Linao, particularly in Sitio Batuan, problems of water and soil degradation were greatly felt among farmers. According to one informant, due to limited water supply, farmers have to depend on the rainfed farming system.

"Kuwang og supply sa tubig kay non-irrigated man, magdepende ra sa uwan. Unya giguba sa baha ang irrigation. Wa jud irrigation diri sa Guinsangaan mismo." (Barangay Guinsangaan is lacking in water supply since there is no irrigation system here - it was destroyed by the flood. We are only dependent on rainfall.)

Occurrence of pests and diseases

Major problems identified in Barangays Guinsangaan and Marao were pests and disease infestations of coconuts, and banana/abaca. For coconut, Brontispa longissima infestation has affected the harvest of the crop. As one resident said:

"Ang problema run sa lubi kanang sakit ba, kanang mukalit og kamatay ang ijang udlot, masunog, mukalit ra og kupos. Akong gitan-aw, unya inig mamatay ang dahon, naa sijay mura og mananap nga taas, bug ba na? Kanang gagmay ba." (The problem with coconut is the disease wherein the shoots dry up. I inspected it and found that when the leaf dies, an insect comes out, is it a bug? These are small insects.)

For other crops such as banana, the disease locally named as "bugtok" has threatened the crop. Likewise, the problem of bunchy top had totally wiped out the abaca plantations, which used to be one of the major crops of the area.

\section{Young generations are no longer interested in farming}

Another problem revealed by the residents is that young people have no interest in farming anymore. Many areas are not cultivated resulting in low crop production. As one informant said, their children are no longer interested in planting crops since they are more fascinated with life in the city.

"Nah, dili najud nang mga bata mananom kay kasagaran ganahan moadto sa Manila. Mao jud na dinhi, ganahan naman muadto ug syudad. Wa nay interes kay madaot man kuno ilang beauty." (Young people do not want to plant crops anymore since they want to go to Manila. That is what's 
Participatory Assessment of Resources and Needs of Upland Communities

happening here, they want to go to the city. They have lost interest because they think farming ruins their beauty.)

No space for planting food crops

Participants explained that they have no more space to plant food crops like vegetables and rootcrops because of the many coconuts planted in the fertile areas of the barangays.

"Naa gud mais pero pila ra kabuok, tungod sa lugar nga daghan lubi, naa gud pero gagmay ra kay tungod lubi ra puro ang tanom. Bisan pag abunohan kay wa may init nga makalusot" (There are only a few corn planted since the area is filled with coconut trees. Even if fertilizer is applied, there is still lack of sunlight.)

\section{Low price of copra}

Informants revealed that they could not earn enough income from copra making and selling because the labor wage remains very high even when the price of copra has decreased. As they said, not enough income resulted in not being able to meet the immediate needs of the family (i.e. food, children's schooling, etc.)

"Ang problema pod, ang presyo sa kopras usahay mubarato diba, unya ang imo isuhol sa mga tawo, mao ra gihapon." (The problem is that even when the price of copra is cheaper, labor wage still remains high.)

\section{Illnesses in raised animals}

Some residents who raise animals for a living mentioned that they have experienced problems of illness in fowls locally termed as "tukdaw".

"Mag edad na sija og usa ka buwan o usag tunga, mao jud na nga dali sija masakit. Kanang tukdaw, mao na humok ang balahibo, hubag mata. Labi na ug kanang mu-init unja muolan." (A chicken that reaches a month or a month and a half old is prone to diseases. We call it tukdaw, weakening of the feathers and swelling of the eyes. It happens during sudden change in weather - from warm to cold.)

\section{Food insufficiency}

The problems mentioned by the participants were contributing factors 
to their immediate problem which is food insufficiency. Their eagerness to attend trainings and seminars on farming and food production is evidence that they want to find solutions to this problem. As one resident said:

"Ganahan man pod mi mo-attend ug naay mo-conduct og seminar sa kanang organic farming. Kanang mga pamaagi og asa pwede ibutang ang pananom ba labi na og gamay ra og space. Kana pod unsa nga mga utanon ang bagay itanom sa ilawom sa kalubihan, kanang dili kaayo kinahanglan ug sunlight." (We want to attend seminars on organic farming. We want to learn techniques on where to plant food crops especially when there is not enough space for planting. We are also interested to learn on the appropriate food crops to be planted under coconut trees, those that do not need much sunlight.)

\section{Solutions undertaken}

There were a number of activities mentioned by the PRA participants that addressed their problem of food insufficiency and provided for their basic needs. Among these were the following: food processing and selling, furniture making (lantay and tables), backyard gardening (vegetables and crops), animal raising and selling, working as hired labor, and habal-habal (single motorcycle) or tricycle driving.

\section{IMPLICATIONS}

Analysis of the PRA participants' accounts revealed that the communities' level of awareness on the condition of their environment is limited to the symptoms of the problems, like drying up of springs, reduction in yield of coconut, reduction of soil fertility, and occurrence of pests and diseases.

The solution they identified to address these limitations is to have alternative livelihoods, not to find ways to improve their resource-base. The participants emphasized their need for more livelihood options to supplement their unstable income from coconut. Their eagerness to participate in seminars and trainings that can assist them in their alternative livelihoods is evidence that they want immediate solutions to their food insufficiency problem, which is why they tend to overlook the need for proper community resource management. 
Participatory Assessment of Resources and Needs of Upland Communities

This suggests that there is a need to facilitate paradigm shift among the people in the community. The community's understanding in the management of their resources is important in the planning of activities to sustain their resource base (DENR, 1994). A study conducted by Vega and Mendozain Tabango (n.d.) in Tabango, Leyte revealed that "ownership" of resources is a requisite so that the people will conserve their environment for future generations. To encourage the upland residents of Inopacan to conserve their resource base, they must be made aware on what they can do. This can be done through communication intervention and proper education for environmental conservation.

\section{REFERENCES}

BLAIR, G., and LEFROY, R. 1990. Technologies for sustainable agriculture on marginal plands in Southest Asia: proceedings of a workshop. ACIAR Proceedings (p. 43). Ternate, Cavite: ACIAR.

CHAMBERS, R. 1994. Participatory rural appraisal (PRA): Analysis of experience. World Development, 1253-1268.

CHAMBERS, R. 1994. Participatory Rural Appraisal (PRA): Challenges, potentials and paradigm. World Development, 1437-1454.

CHAMBERS, R. 1994. The origins and practice of participatory rural appraisal. World Development, 953-969.

KAPOOR, I. 2001. Towards participatory environmental management. Canada: Academic Press.

MERCADO, A. R., and SANCHEZ, P. A. (n.d.). Community-based agroforestry practices for watershed management in the Philippine. Los Baños, Laguna.

MOSSE, D. 1994. Authority, gender and knowledge: Theoretical reflections on the practice of participatory rural appraisal. Development and Change, 497-526. 
SAJISE, P. E., and GANAPIN, D. J. 1990. An Overview of Upland Development in the Philippines. Technologies for Sustainable Agriculture on Marginal Uplands in Southeast Asia (pp. 31-43). Ternate, Cavite: ACIAR.

VEGA, B. A., and MENDOZA, J. D. (n.d.). Benefits from tree growing in the degraded uplands: Empirical realities from Tabango, Leyte, Philippines. 